\title{
WHO MURDERED JOE MAGARAC?
}

\author{
Ivan Kovacevic
}

\begin{abstract}
The article examines the origin of an American steel industry mythical hero, Joe Magarac. The analysis is based on the original text by Owen Francis from 1931 and aims to resolve a dilemma - whether the text is genuine folklore or fakelore. The analytical method is layered and varied; it involves comparing Francis's text to other elements of folklore from the host country, confronting the meaning of the legend of Joe Magarac with the genuine interests of steelworkers, and contextualising the legend in the social conflicts of the steel industry in Pennsylvania at the end of the 19th and the beginning of the 20th century.
\end{abstract}

Keywords: America, Joe Magarac, immigrants, mythical hero, Pittsburgh, steel industry, workers

\section{THE BIRTH OF JOE MAGARAC}

Bearing in mind that Joe Magarac, a significant American figure of Pittsburgh steel plants, is considered both a folklore and fakelore hero, it is reasonable to expect that there would be at least three stories about his birth: one of folklore, another of fakelore, and a folkloristic tale. As far as the last one is concerned, folklorists find that Joe Magarac was born in a folklore story and his emergence can be traced as early as the year 1931, to the text by Owen Francis published in Scribner's Magazine, in which Joe Magarac was first mentioned. Francis's initial version of Magarac's story places his birth in a steel ore mountain or steel mine. However, by introducing Dorson's notion of fakelore and by applying that notion to the stories of Paul Bunyan and Joe Magarac, the folklore basis of this character is negated, thus leaving his origin a blur. Defolklorising Francis's version of the Joe Magarac saga makes establishing the third variant of the origin of "the man of steel" seem impossible, for if it is not folklore then the folklore story of Joe Magarac's birth does not hold weight. 


\section{HISTORY}

Francis's story of Joe Magarac (Francis 1931) begins with a detailed account of the planning of a weight-lifting contest, organised by Steve Mestrovich, who aims to present the winner with the hand in marriage of his beautiful daughter, Mary. At the contest, which consisted of lifting three dolly bars of increasing size, the second bar was lifted by three contestants: Elli Stanowski, Pete Pussick, and some man from Johnstown, who was locally despised as a resident of a rival village. When none of them managed to lift the third bar, Joe Magarac appeared.

He was more than six feet tall, with shoulders broader than two doors, his hands twice as big as those of Elli and Pete together, and his bulging muscles wider than an average waist. Joe had picked up the heaviest dolly bar together with the Johnstown contestant. Then he introduced himself to the crowd: "My name is Joe Magarac [...] all I know is to work and eat like a donkey. I'm the only man of steel in the world. Behold...". Then he lifted his shirt for everyone to see that, indeed, he was made of steel - hands and legs, his whole body. However, once he discovered that his reward was the hand in marriage of the beautiful Mary, he declined it, explaining that he had no time to sit at home with a wife since he spent all his time working at a steel mill; he added that Mary deserved a far better husband and that he had noticed her "bafflement" whenever she looked at Pete. Joe and Steve winked to one another, and Mary and Pete were exceptionally joyful.

Joe made steel rail tracks with his bare hands, and he was so good and fast at this that in no time there were railroad tracks everywhere in the region of the steel mills. This led to the closing of several mills for a few days. When the steelworkers returned to the factory, they found Joe melting in a furnace; he explained to them how he could not get over the mill closing and that the steel into which he would melt would be the best that was ever made.

\section{ETHNICITY MISHAPS/TROUBLE}

Various ethnic identity discussions are related to the character of Joe Magarac. This is not at all surprising, considering the American lack of comprehension of immigrant ethnic relations at the time the Joe Magarac saga was created. Joe's special circumstance was created from a generalised notion that was used as a signifier to encompass several ethnic groups; these groups represented the majority of Pittsburgh's labour population in the second half of the 19th and the first half of the 20th centuries. The words in question are "Hunkies" and 
"Hunkietown", which denoted various ethnic groups as well as the places they inhabited. Webster's dictionary states that the word "Hunky/Hunkie" originated as a modification of the word "Hungarian", meaning, mostly derogatorily, a person born or descending from Central and Eastern Europe (see http://www. merriam-webster.com/dictionary/hunky). When examining the Hunkies' ethnic structure in one of the steel mills in Pennsylvania in 1919, it becomes clear that Slovakians, Hungarians, Croats and Serbs accounted for more than half of the workforce of non-American background (Foster 1920: 195). Keeping in mind that previously immigrated workers, who were of English, Irish, Scottish, Welsh, German and Scandinavian background, had more complex and betterpaid jobs at the same factory, and were not considered to be "foreigners", unlike the Hunkies, it is obvious that the four ethnic groups mentioned above represented the majority of the "Hunkietown" (ibid.: 196-197). Therefore, it is understandable that one of the characteristics that these four ethnic groups had in common led to the same denomination for all the four, which was derived from modifying the word "Hungarian". What Slovakians, Hungarians, Serbs and Croats had in common was citizenship; they were all citizens of the Kingdom of Hungary, which was formed by the Austrian-Hungarian Compromise of 1867. The duality of the term "Hungarian" led to great confusion over Joe Magarac's ethnic background: it was initially described as Hungarian but later came under further discussion. C.J. Reutter (1980) had successfully debated against earlier interpretations of Joe Magarac being either Slovakian or Hungarian, proving them untrue. By adopting the interpretation of Croat Hrvoje Prpic, Reutter concludes that the word "magarac" is actually a Croatian word (meaning 'donkey') and that Joe thus must be a Croat, but he obviously overlooks the fact that the word is Serbian as well, which was raised by Marshal Fishwick (1954).

On one hand, the debate concerning the ethnic identity of Joe Magarac looks as if it is about a real historic personality and that some birth certificate would resolve the entire dilemma. Those involved in this debate had, however, thought it was a folklore creation and that they could thereby establish which ethnic group had created the character of Joe Magarac and thus contributed to American mythology. Nevertheless, by deconstructing the Joe Magarac story and branding it as a fakelore creation, at least on the surface, makes such research ill-founded. However, to understand the context under which Joe Magarac was created, the significance of knowing the true meaning of the word 'magarac' was substantial, so the ethnic circle of those who understood the word was narrowed down to Serbs and Croats.

In light of this state of language competence or, alternately, (un)familiarity, all the confusions that arose through the myth-creation wanderings become visible, as do various guesses on Joe Magarac's origin and background. For 
example, the hypothesis of a Hungarian writer from Pittsburgh, George Sechkai, featured his memories of a story about a certain Hungarian fellow, Andrew Catona, who rose from being a shepherd in Hungary, through a participant in the Hungarian revolution, to working as a police officer in America and as an employee in a company, and whose task was to spy on other workers, for which he was hated and called "Magiaron" and "Magarac" (Fishwick 1954: 172). Regardless of the fact that in both cases the nicknames had been ethnonyms, "Magiaron" and "Madjarac", Fishwick used Sechkai's memories to deconstruct the mythology that ensued after Francis's text.

\section{FOLKLORE OR FAKELORE?}

The dilemma of folklore or fakelore - the latter a term established by Richard Dorson $(1959 ; 1976)$ - is present in any consideration of the character of Joe Magarac. Dorson's analyses of such analogue characters as Paul Bunyan or John Henry, and the arguments that bolster their fakelore origin, as well as the further destiny that Joe Magarac's character suffered in numerous, amusingly inspired literary stories, whether due to the needs of the company or the state, imply that Joe Magarac, too, joins the gallery of fakelore characters. Any folkloristic effort of interpretation is obstructed by the inability to prove the veracity of Francis's (1931) article, Blair's (1944) reference to other people's earlier notes, or Carver's (1944) citing a story of a Hunkie. However, at the base of Dorson's dichotomy lies a belief in the existence of a "true", "authentic" folklore as made through the collective creation of the group, and any individual or organised creation can only be fakelore. Even if the dualism of folklore and fakelore was this simple, the faith of many fakelore creations shows that they went through a process of folklorisation and that they became a legitimate part of collective storytelling. At the time Dorson established his dichotomy, the notion of popular culture and its relationship with folklore was out of reach of folkloristic thought, whilst today such discrimination is quite often impossible. This path of folklorising the fakelore saga of Joe Magarac is told in J. Gilley and S. Burnett's review of the story's development (Gilley \& Burnett 1998), which, again, does not exclude the possibility of looking into its folklore potential.

When analysing the story in its historical context and comparing it to the interests of the steelworkers, for whom Joe Magarac is supposed to be a hero, everything leads to the conclusion that it was classical company fakelore as advocated in Dorson's (1959; 1976), Richman's (1953) and Fishwick's (1959) theses. At the base of fakelore heroes, Dorson holds, is an interest in the capital for which "money-writers" create such heroes, and the wrong idea about the au- 
thenticity of these "folk heroes" is spread by teachers, librarians and the general public; these ideas are incited by money-writers and those who promote them (Dorson 1959: 4, 215). However, at the time of the biggest public promotion of the Magarac story - in Francis's text in Scribner's Magazine from 1931 - the times of great and harsh social turbulence, like the Homestead Strike of 1892, were bygone times, and decades had passed since the Great Strike. The tension between workers and companies, or unions and companies, was still present, so the need for such company fakelore was quite palpable. Then again, there is no folkloristic evidence of Joe Magarac before 1931, nor are there hints of any documents existing that would sustain Dorson's thesis that this was a fabrication of the PR department of the US Steel Corporation. The later participation of the company in the making of a children's comic about Joe Magarac speaks of the instrumentation of the already-made character (Dorson 1959), but it does not articulate their direct involvement in the creation of the character.

With the lack of reliable documents, both hypotheses about the origin of the story are possible, bearing in mind the fact that thus far analyses of its meaning have given more credibility to the fakelore thesis, stemming from the discrepancy between the interests of the workers and the incessant work of Joe Magarac. Nevertheless, the saga contains elements that support both the folklore thesis and its later fakelore twist.

\section{OWEN FRANCIS AS A FOLKLORIST}

One of the questions that this article aims to answer is whether Francis's story is true fakelore or complete fakelorisation, which ensued through later versions. Therefore, this author includes a detailed analysis of Francis's version of the Joe Magarac saga.

Owen Francis was himself a screenwriter and short story writer. He began his career in the steel mills of Pennsylvania after participating in World War I and while recuperating from gas poisoning; he received his education at the University of California, and after initial failures with movie screenwriting, he returned to Pennsylvania (Fishwick 1959). After being disappointed by the super-sophisticated Hollywood, he returned to the Hunkies and the Polish, who "understood life". Describing his intentions, Fishwick says that Francis, "even though he had neither formal interest nor contact with the folklore, decided to invent the mythical steel hero", and that he did it in order to sell such a story. ${ }^{1}$ Dorson attributes a similar motive to Francis, qualifying him, along with other creators of fakelore heroes as a "money writer", in whose childish imagination characters like Joe Magarac were conceived (Dorson 1959: 215). 
A question arises if, after such a clear differentiation of Francis's texts from folklore, it is at all possible to question the fakelore character of the Joe Magarac saga. The saga has to be examined in the context of American folklore of the first three decades of the 20th century in order to ascertain whether there are indeed any elements of folklore in Francis's text.

When Francis was writing the Joe Magarac saga, American folklore was mainly based on amateurism and enthusiasm. The possibilities of an education for a folklorist were poor. According to P. Boggs's research from 1940, in earlier times there were only four universities in America that offered specific folklore studies, and only 23 universities had folklore courses, the majority of which focused on ballads (Boggs 1940).

If Francis's text is viewed from this perspective, a different picture forms. First, Francis speaks out of his own experience, his life and active participation in the steel mills of Pennsylvania; he refers to Slavic workers, whom he had heard many times calling each other "magarac" ('jackass') (Francis 1931: 505). Francis then moves on to explaining how he had spent many a night in the houses of the Hunkies and had the luck to hear the Joe Magarac story repeatedly on those occasions; this represents the description of fieldwork research, which folklorists of his age would not overlook. ${ }^{2}$ What Francis did next does not deviate from standard folkloristic practice. He pointed to the formal likeness (and difference) that Joe Magarac shared with Paul Bunyan's or Old Stormalong's stories. In 1931 it was impossible for Francis to have known of Paul Bunyan's fakelore origin, which Dorson ascertained a few decades later (Dorson 1956; 1959). A third, fairly regular folkloristic procedure, which can be identified in Francis's text, was the effort he made in trying to find out whether there were any truthful connections between the Joe Magarac story and the folklore of any country from which the Hunkies came:

Although the stories of Joe Magarac are sagas, they have no tangible connection, so far as I have been able to find, with the folklore of any of the countries which sent the Hunkie to these United States. (Francis 1931: 505)

His lack of formal folkloristic education is reflected in this last effort, although it was rare in America to have been educated in folklore during the first decades of the 20th century. Although he tried to connect Joe Magarac to identical characters in the folklore of the countries from which the Pennsylvania steel mill workers came, Francis's search for a connection produced an expected result. However, when one examines the elements of the story as integrated into a new, more functional whole, it is possible to perceive a new image. 
A few features of "old country" storytelling can be recognised in Francis's story of Joe Magarac: the element of having to pass a difficult trial in order to win the bride, the victory one achieves in such a competition for the benefit of someone else, and the "steel man" motif. The fact that such motifs can be found in the folklore of other European nations bears no significance, since the relevance of the Joe Magarac tale is that these themes exist in the folklore of those ethnic groups among the Hunkies, who also have the word "magarac" in their vocabulary.

More generally, the difficult tasks ahead of folklore protagonists who want to win someone's hand in marriage appear in different forms: from a duel between knights, to outwitting or overcoming high hurdles, to archery. Duels and strenuous tasks are elements of the famous epic poem Dusan's Wedding (Karadzic 1845), while candidates that outwit the girl's father or the girl herself are present in many tales from Vuk Karadzic's collection (Karadzic 1853; 1870).

In The King and the Shepherd fairy tale, which Vuk Karadzic published in 1853, the shepherd completes the difficult task to win the bride. After the task is completed and the shepherd - who, in a competition of cleverness against the king - wins the princess, he addresses the king:

"I have outwitted you quite enough, now give the girl, for I have deserved her." The king saw no way out of the situation, so he gave the girl to the shepherd, and the shepherd surrendered her to the rich man, who in exchange awarded him with immeasurable treasure. (Karadzic 1853)

Joe Magarac acted the same way after he had won the contest that Steve Mestrovich had organised: he gave the beautiful Mary to Pete Pussick and a wink to Mestrovich, saying he had no time for anything but work and that he had noticed Mary's bedazzled look whenever she laid eyes on Pete (Francis 1931).

In The Man of Iron ${ }^{3}$ (Karadzic 1870) fairy tale, which Vuk Karadzic wrote before 1853, the main character (the king's youngest son) is married to a frog, which later turns into a beautiful woman and causes her mother-in-law to feel jealous. The mother-in-law (the queen) makes her husband give his son difficult tasks, which he overcomes with the help of his brother-in-law, who lives in the well, out of which his wife (the frog) was taken. After two successfully accomplished tasks (with the help of his brother-in-law) the king's youngest son is given the third task:

Some time later the king summoned his son again, and said: "I hear you brag about being able to bring the iron man." The poor prince started negating the story, saying how such a thought had never even crossed his mind, and the king replied: "Not one word more; unless you do it, 
you will lose your head." The poor prince then went to his wife in tears, and when she saw him crying, she asked: "To what are those tears?" And the prince recounts the sad ordeal to her. Then she said: "Go to the well again and shout: 'Brother-in-law,brother-in-law!' He will answer and be cross so he will reply: 'To hell with such a brother-in-law.' But then you tell him: 'For God's sake! I'm driven by misery!' and tell him everything." The prince obeyed his wife and when he got to the well he started calling out: "Brother-in-law,brother-in-law!" His brother-in-law responded in an angry voice: "To hell with such a brother-in-law, what do you want this time?" And the prince said: "For God's sake, my brother-in-law, a great misfortune befell me: my father asks of me to bring him the iron man so he could speak to him." Then his brother-in-law answered: "Wait a minute, I'll be up in a moment, but don't be scared or petrified." And the next thing, the iron man was standing before the prince. Oh, he was tall and frightening! Dragging a mace, with which he ploughed the land, leaving a trail behind as if eight strong oxen had ploughed instead. When the king saw from afar that the iron man was coming, he felt very scared, rushed into the castle, bolting all the doors behind, and fled to the highest tower, in which he locked himself. When the iron man came to the door, he started knocking politely to be let in, but when he realised that no one was answering, he launched his fist at the door, which broke in half on the spot; the iron man opened all the doors in this way and came before the king. When he stood in front of the king, he asked: "Why have you sent for me?" but the king fell dumb. "What in hell's name have you to speak to me about?" said the iron man, and chucked the king on the forehead and the king fell dead on the spot. Then the iron man put his brother-in-law on the throne and proclaimed him the king, and so the youngest son lived and ruled with his wife to the end of his days.

None of these elements, not even the description of the gigantic man of iron, should be attributed with any significance for the conception of the Joe Magarac story. The latter story was made up for quite different purposes versus typical folk songs and tales, but the elements of "old" folklore that were "at hand" are indeed useful for creating the story of a new world and rather new social circumstances. 


\section{JOE MAGARAC IN THE TYPOLOGY OF THE STEELWORKERS' STORIES AND SOCIAL TYPES}

The Joe Magarac legend is an example of how it is possible for a character with qualities diametrically opposed to a certain social group to be imposed onto that same group as their 'hero'. Joe Magarac is the personification of anti-worker interests, which has been stated in a certain number of analytical studies, even in myth-creation texts, in which one of the creators of the myth stated that working fast builds animosity from other workers. ${ }^{4}$ Gilley and Burnett state that "magarac (a jackass) is something that workers find to be an irrational super-worker" (Gilley \& Burnett 1998: 397). These authors try to align the Joe Magarac saga with Jack Santino's typology of workers' stories (Santino 1978). Santino distinguishes three main types of workers' stories: a) cautionary tales, in which inappropriate on-the-job behaviour leads directly to some sort of avoidable accident or calamity; b) trickster stories which centre on hostility toward authority, realised by a prank that a subordinate worker plays on a superior or a new co-worker; and c) stories of work heroes which, among other things, praise the physical strength of the worker. Gilley and Burnett state that at first glance, Joe Magarac belongs to the category of work heroes possessing enormous physical strength. According to Santino, those workers' stories are based on bringing human characteristics up to their extremes, like rail constructor John Henry - who, according to classical interpretations of the ballads, died of the consequences of competing with a machine. John Henry's story was, along with the tale of the more famous "lumberjack" Paul Bunyan, the subject of a noteworthy analysis to ascertain its folklore-fakelore nature (Dorson 1965: 155-163). ${ }^{5}$

The story of running away from molten steel is about exaggerating and reaching those limits, but within human possibilities. The story that Fishwick presents, about a man who, unprotected, went into a room in which the steaming hot molten mass flooded in, and who later "broke" the world record in running, was told in the steel towns where physical strength and endurance were appreciated (Fishwick 1959: 172-173). ${ }^{6}$ That is why the element of fantasy is crucial for understanding Joe Magarac, according to Gilley and Burnett: keeping in mind the fact that he is not human but "made of steel", Magarac thus represented "the summation of what the capital asked in its workers and not the hero of the working population" (Gilley \& Burnett 1998: 398).

Magarac was the opposite of everything for what the immigrant workers were striving: he consciously chose to live in extremely poor conditions, like those in which the actual immigrants lived but which they wanted to escape 
by fighting in the Homestead Rebellion of 1892 (Burgoyne 1893) and the Great Steel Strike of 1919. He also refused to get married and start a family, which was the antipode of the American standard idealised by the immigrant workers (Report 1920; Foster 1920).

Thus, Joe Magarac could not have been the mythical hero of the Pittsburgh immigrant workers; rather, he would fit into the "Rascal" character, and, more precisely, its subtype, the "Renegade", in Orin Klapp's (1956: 337-338) typology. On the other hand, the sneer and ridicule shown to Joe Magarac makes him similar to the "Fool", particularly its subtype, the "Common Fool" (Klapp 1949: 157), whom Klapp describes as naïve, crude, insensitive, and characterised by funny failures, comic frustrations, inexplicable behaviour and being taken advantage of by others. As far as possibly being a hero in American culture, according to Klapp's classification, Joe Magarac falls under the "Martyr" type; however, he is a martyr for the cause of the company and not for the rights of workers (Klapp 1948: 137).

\section{COMICAL OR MYTHICAL HERO?}

The majority of analytical texts examining Joe Magarac in a way declare a humorous touch to the tale. From "the spirit of gargantuan whimsy", of which Dorson (1977: 215-226) speaks, to Gilley and Burnett's text in which the authors emphasise the story's "satirical character", all assessments underscore elements of humour that remain unexplained. In the case of classic fakelore arguments, the author(s) would probably avoid the complicated semantic pun affiliated with the word 'magarac' (jackass) or 'mazga' (mule). Francis himself had that problem, stating that the notion that the word 'magarac' was a compliment caused laughter; this was decisively confirmed by Richman (1953: 287), who concluded in the field that "the word 'magarac' is never used without a sneer". Thus, Joe's last name can be attributed to folklore rather than to fakelore choice. Fakelore choice would avoid negative connotations for the last name of a hero who was imposed on immigrant workers, while the folklore choice is intentional since all the other characters in the story have common last names - for example, Mestrovich and Pussick (which are almost entirely Croatian). This means that the last name of Magarac contains the semantics of the word 'magarac', which is entirely a sneer when applied to people. ${ }^{7}$ Academic dictionaries define the word 'magarac' as "vulgarity of an ignorant person" (Rječnik 1907) and as "the one committing stupid acts and flippancies, stupid, unintelligent person, a foolish idiot [...and a] stubborn, obstinate person" (Rečnik 1981). 
The semantics of the main character's last name thus transform it into mocking a person who has no pleasures but work and who declares himself too occupied for anything but work. His refusal of the hand in marriage of a beautiful girl means that he is turning down something that is the dream of every young Hunkie, which even more highlights the ridicule aimed at Joe's devotedness to work. The same goes for the end of the story, when Joe kills himself, not because he is left without work but because the mill closed down.

In considering the Joe Magarac saga against Santino's typology of workers' stories, Gilley and Burnett rule out the possibility that this is a trickster story, citing, "If this is a trickster story then the only one duped by it is Owen Francis" (Gilley \& Burnett 1998: 397). How seriously Francis was duped, and how much his text actually served as a major twist in the Joe Magarac story remains a question that can be answered indirectly.

One possible approach is to view the story of Joe Magarac in the context of Jauss's typology of relations with the hero (Jauss 1974). Jauss differentiates five types of identifications with the hero: associative, admiring, sympathetic, cathartic and ironic. The typology's application to the story of Joe Magarac is more specific, inasmuch as it refers to the identification within the story itself as displayed by observers of Joe Magarac's actions, whilst the possible folk nature of the story's identification refers to both the storyteller and the audience. Jauss's typology is manifested in all its types in the order that Jauss states. Namely, in the weight-lifting competition, the identification with Joe is associative; his victory causes admiration; sympathy occurs when Joe is shown as an imperfect hero and when he refuses to marry the beautiful Mary. Catharsis occurs when Joe kills himself because the factory stopped working, and an ironic identification stems from viewing the entirety of his harmful influence on the workers in the steel mill. If this identification is viewed in a less rigid manner, the divinisation of the beginning of the story is visible, which Jauss defines as associative and admiring; however, this appears less sincere than sympathy, which can be ironic, as well as less sincere than the irony itself, while the catharsis perfectly solves the problems that Joe creates for the workers. In this way, Joe Magarac is exposed as someone whom the audience falsely admires and with whom they falsely sympathise in his imperfection, and yet they simultaneously laugh at him and are happy to see him go. 


\section{JOE MAGARAC AND DUTCHMAN SCHMIDT (FREDERIC TAYLOR)}

Gilley and Burnett, in their text about the deconstruction and reconstruction of the Pittsburgh "Man of Steel", hint at the possibility of perceiving the character of Joe Magarac in light of Taylor's scientific workplace organisation. They refer to Taylor in the description of the workers' reaction to their arduous and monotonous work role, and to his description of the workers slowing down the work, which he named "soldier (or military) behavior" (Gilley \& Burnett 1998: 398). However, the importance of including Taylor's work and Taylorism while considering Pittsburgh's "Man of Steel" is far greater. It is a commonly known fact that Taylor made the first developments in "scientific workplace management" in Pennsylvania, actually in the steel industry, although not in Pittsburgh but in Johnstown and Bethlehem, the other two centres of Pennsylvanian steel industry. This fact points at the historic parallelism of the workers' rebellions and strikes and the incorporation of Taylorist principals in the production process.

Describing one of his first attempts to implement "scientific work management" in Bethlehem at the beginning of the Spanish-American War in 1898, Taylor writes that one of the first steps was the "scientific selection" of workers (Taylor 1915 [1911]: 43-48). After he had primarily aimed to increase workers' daily performance up to loading 47 tonnes of steel instead of 12.5 tonnes, Taylor had carefully observed those workers who loaded 12.5 tonnes, using the old technique for a wage of $\$ 1.15$. First, he singled out four men and studied them in detail by examining their past, character, habits and ambitions; Taylor finally chose one Dutchman whom he had named Schmidt. While he was observing Schmidt, he noticed that the man was walking home from work looking as fresh as when he came to work in the morning, that he had managed to save some money of his wage (which was the same for all workers) to buy a piece of land, on which he was building a house, and that he was very "tightfisted" i.e., he valued every dollar he had earned. In a dialogue with Schmidt, which he recorded in The Principles of Scientific Management from 1911, Taylor had insisted on using Schmidt's self-respect as a motive for accepting an utterly disciplined workload with four times the volume, and for 60 percent higher income. Schmidt's accomplishment in loading raw steel became a benchmark for all other workers:

As each workman came into the works in the morning, he took out of his own special pigeonhole, with his number on the outside, two pieces of paper, one of which stated just what implements he was to get from the tool 
room and where he was to start to work, and the second of which gave the history of his previous day's work; that is, a statement of the work which he had done, how much he had earned the day before, etc. Many of these men were foreigners and unable to read and write, but they all knew at a glance the essence of this report, because yellow paper showed the man that he had failed to do his full task the day before, and informed him that he had not earned as much as $\$ 1.85$ a day, and that none but highpriced men would be allowed to stay permanently with this gang. [---] So that whenever the men received white slips they knew that everything was all right, and whenever they received yellow slips they realized that they must do better or they would be shifted to some other class of work. (Taylor 1915 [1911]: 68-69)

In this way, a particularly chosen and trained worker became the work standard for everyone, and his performance became a norm on which the wages were based. At the base of Taylor's "scientific work management" was the principle of measuring up to the best, strongest, fastest, deftest - which directly jeopardised everyone else and made him the source and target of union organisations.

Even during Taylor's lifetime there was political debate about his system of favouring the paramount of workers. When the workers at a state cannon factory in Watertown raised their voices against the implementation of Taylor's method for measuring the time required for a certain job (Aitkin 1960), a congressional committee was formed, which investigated the situation as well as Taylor himself. Upon Taylor's discourse of "first class men" benefitting from his system, the chairmen of the committee, William B. Wilson, asked him emphatically about the faith of those who were not "first class (rate)" (Kanigel 1997: 21). The fight of workers and unions against Taylorism marked the 20th-century industrialisation, starting from individual protests, then collective uprisings like the Homestead Rebellion of 1892, to the great strikes - of which the most familiar was the one in 1919 - and strong organising into unions in the first half of the 20th century.

Taylor's notion of "first class (rate) men", his description of Schmidt's characteristics and the drill faced by Taylor's chosen super-worker make possible another interpretation of Joe Magarac. It is quite reasonable to imagine some other Schmidt - perhaps by the name of Joe - who was strong, obedient and motivated by a higher wage to set the performance norm for others. The illiterate Hunkies, after finding out whether they had fulfilled the norm from the colour of the paper, showed growing hostility toward super-worker Joe, calling him foul names in their own language. From such a situation, another, apparently irresolvable situation could have arisen quite easily: the former idol and hero of 
workers being called a 'magarac', or a 'jackass', which neither his later creators (for the sake of the company) nor folklore analysts could handle. In this way, Francis's informers earn credibility, which does not diminish Francis's role in creating a base for a "workers' hero", who acts in the interests of the company. The question is whether 'magarac' is a direct, general typological reference for a super-worker - who, according to Taylorist methods, created exceedingly high performance standards - or is it just that some Schmidt-like person was called a 'magarac' (jackass) by the Hunkies whose mother tongue was Serbian or Croatian. This will probably remain unanswered, exactly because of the fakelorist connotation of a great number of articles about Joe Magarac in the period from Francis's text to Dorson's determination of fakelore, which wasted the time that the story could have actually been confirmed by the then still living Pittsburgh steelworkers. Based on this definition of Joe, who was called a 'magarac', it can be surmised that all the 'research' on his ethnic identity went in the wrong direction and that Joe need not have been a Hunkie at all, although this too is possible. Nevertheless, it is more likely that the Hunkies had been outside of the choice for a super-worker; the super-workers were more likely Americans or those workers whose ethnic groups sooner reached Pennsylvania and had better knowledge of English, which made them all the more suitable for learning and Taylorist drilling than the illiterate Hunkies. Accordingly, the most probable answer to the question 'Was Joe Magarac a Serb or a Croat?' would be: he was neither. Joe could have been an American, or a German or a Dane, like Taylor's Schmidt; that is, anyone who was setting the norm in the name of the company, by which the wage was then determined. Evidently, though, he could not have been a part of 'the workers' community', but was instead a defender of the company.

\section{THE FALL INTO THE MOLTEN STEEL}

If the character of Joe, sneeringly called a 'magarac', can be interpreted in this way, then so can his 'death' in molten steel. The fakelorisation of Joe Magarac and his transformation into a workers' superhero, with the characteristics of Superman, cannot successfully resolve how his death in molten steel may be heroic and tragic, yet at the same time satirical and darkly humorous.

Joe's death can be observed in two ways. The first is via the social context, that is, the relation between the illiterate and unskilled workers (in this case, Hunkies), and the exponents of the company (superintendents, super-workers, etc.); the second is through the technological-legal context of the innumerable 
accidents that were happening in Pittsburgh and other steel mills in Pennsylvania, which took a great number of lives.

In order to understand the relationship between steelworkers and representatives of the company, particularly those with whom they had direct contact, Frederic Taylor's own experience can be cited, when he was first elevated to the line of 'company men'. When Taylor was first promoted to a 'gang-boss', while he was working in the Midvale Steel Company in Johnstown, the workers, with whom he had shared the same duties up to that moment, all directed to him the same unequivocal threat:

Fred, we're very happy you've been made a gang-boss. You know the game all right and we're sure that you're not likely to be a piece-work hog. You come along with us and everything will be all right, but if you try breaking any of these rates you can be mighty sure that we'll throw you over the fence. (Taylor 1915 [1911]: 49)

A great number of work-related accidents and deaths represent another context in which to perceive Joe's death. In a separate study, which was devoted to work-related accidents in Pittsburgh, Crystal Eastman concluded that in one year alone (from 1 July 1906 to 30 June 1907), there were 195 death cases in Pittsburgh and 526 in Allegheny County (Eastman 1910: 11, 64). Out of those 195 cases in Pittsburgh, 24 (or 10\%) were caused by a fall, like the one the workers threatened would happen to Taylor. State law in Pennsylvania demanded a report of every serious incident, but companies consistently broke the law by writing the reports but never making them publically available (ibid.: 64). That means the investigations and the findings remained within the company (which could choose to suspend its interrogation), even when there was a death. Under those circumstances, the threats that Taylor experienced seem very serious, since among the many accidents not further investigated, one case would not really stand out.

The lack of detailed incident reports - and, what is more, their huge number - calls into question whether Joe, called a 'magarac', was actually pushed into molten steel, or whether that was one of the idle dreams of the Hunkies in order to get rid of the super-worker that lowered their wages and increased their workload. 


\section{JOE MAGARAC AND THE MARKET ECONOMY}

Joe Magarac also had to disappear because he stood against the market economy. The legend kills him by suicide in molten steel, which is one possibility; the other option could place him, the one who put other workers in jeopardy, similarly into molten steel, or on the ground, but not of his own volition. In that sense, the legend has a happy ending, because it eliminates Joe as the creator of workers' predicaments, those being an increased workload, on the one hand, and losing their jobs, as the final consequence, on the other. Not even the fakelore version, which starts from the interests of the company, can leave Joe Magarac alive. His suicide resolves a logical contradiction between aspiring toward absolute production increases and the limited market demand. The folklore version even 'closes' the factory for a few days, and upon reopening they find Joe in the furnace, because it is not in the workers' best interest to go unemployed, while Joe's death removes the major norm increase with a minimal or non-existent wage increase. Also, the fakelore version cannot 'keep' Joe Magarac because the company is not the one controlling the demand of its products on the market, nor does the further production expansion lead to higher profits. On the contrary, hyper-production of a certain product leads to a drop in its price on the market, and finally leads to shutting the business down.

Elementary market logic and its realisation in everyday life makes a character like Joe Magarac a "Common Fool", who sacrifices for the company, in the eyes of the workers, or a "Traitor", who betrays his social group for a meagre wage increase. From a company standpoint he is a "Martyr", who benefits the company far more dead than alive, and from whose character elements a further fakelore construction of a mythical 'hero of the workers' can be constructed.

\section{FROM A SUPER-WORKER TO A WORKERS' SUPERMAN}

The saga's twist, when Joe Magarac was transformed from an enemy of the workers - the raw strength worker and a mindless wage earner - into a hero of the workers and a Superman, could not have unfolded without consequence. Not even the writers reporting after Francis could deal with the main character's last name, with the possibility that his devoted work would not lead to shutting down the factory, or with the sneer that met his refusal to take Mary's hand in marriage. If the latter could have been justified by Joe's feeling that Mary should marry the one she truly loved (Pete Pussick), then avoiding the last name 'Magarac' was the only obvious way. Thus, George Carver changed 
Joe's last name in his 1944 text into 'Magerac', distancing the original 'Magarac' of Francis's text. Another instance testifies to Carver's consciousness of this change - that he had understood from Francis's text that the word 'magarac' has a derogatory meaning - and he explicitly tries to divert attention from that fact. He begins Joe's story with the following sentence: "Joe Magarac - the name has no significance as far as I could learn - was born..." (Carver 1944: 132). All the writers with interests in the company, who made Joe Magarac to be the workers' hero, had to solve the unsolvable - to transform someone who embodied the opposite of the workers' interests, someone whose actions caused uprisings, such as the Homestead Rebellion and the Great Steel Strike, into a character that workers would admire. This change, while causing trouble for the writers, added the "comic and humorous" elements as well, since these qualities were the only way to soften the transformation.

This is why it is possible to conclude that the character of Joe Magarac was conflicted even during his Tayloristic lifetime. He was perceived by the company management as a real super-worker, as a means of speeding up production processes and lowering workers' wages, or at least as a preventive measure against their demands for a pay rise and better working conditions. The other side, the workers' perspective, opposed the managerial ill-treatment; furthermore, in their struggle all resources were allowed - from violence to folkloric and satiric approaches.

The only way of 'survival' for Joe Magarac is outside of the logical contradictions: as an abstract, de-ethnicised, denominated mythical creature, one who does not devote himself to production but instead has the role of the protector, just like Carver describes him, attributing such a depiction to Gregory Ipanovich. In Carver's story, he saves the workers from a furnace explosion, from a crane falling on them, or from a flooding river that transported products from the steel mill (Carver 1944: 132). That version eliminates all contradictions in the workers' or company versions, enabling Joe to appear whenever he is needed, without disturbing the production process. For Magarac to become embodied in this way, he has to be de-materialised without any trace; thus, for the purpose of creating a Pittsburgh-based identity, the folklore tale is very convenient. 


\section{NOTES}

1 As a proof of Francis's intentions, Fishwick cites that a month after the Joe Magarac saga was published in Scribner's Magazine, another, similar story was published about the death of Joe Zimmich, who was also a super-worker like Joe Magarac.

2 Francis describes his experience "in the field" as at the very factory or in the hills above it, or most often in "Agnes's kitchen with Hunkie friends at my side".

3 On the meaning of The Man of Iron fairy tale in the context of "trials obtaining a hand in marriage", see the interpretation of Dragana Antonijevic (1991: 46-68).

4 In Walter Blair's version from 1944, which was based on the notes of J. Ernest Wright, folklore collector for the federal Works Progress Administration, the dialogue between Joe Magarac and his co-workers, who hold his working habits against him, nonetheless ends amicably (Gilley \& Burnett 1998).

5 According to the latest interpretation of historian Scott Nelson, John Henry was a convict serving forced labour, and died of the consequences of silicosis, i.e., poisoning caused by dust from minerals due to years of drilling tunnels (Nelson 2006).

6 It is obvious that the story of running away from molten steel primarily aligns with Santino's cautionary tales, as well as elements of the stories praising the physical strength of workers.

7 Gilley and Burnett state that the corporate version tried to transform the jackass into a mule, as a less derogatory description.

\section{REFERENCES}

Aitkin, Hugh G. J. 1960. Taylorism in Watertown Arsenal: Scientific Management in Action. Cambridge, Mass.: Harvard University Press.

Antonijevic, Dragana 1991. Značenje srpskih bajki. [The Meaning in Serbian Folk Tales.] Beograd: Etnografski Institut SANU.

Blair, Walter 1944. Tall Tale America: A Legendary History of Our Humorous Heroes. New York: Coward-McCann \& Geoghegan Inc.

Boggs, Ralph S. 1940. Folklore in University Curricula in the United States. Southern Folklore Quarterly, Vol. 4, pp. 93-109.

Burgoyne, Arthur G. 1893. Homestead: A Complete History of the Struggle of July, 1892,

Between the Carnegie Steel Company, Limited, and the Amalgamated Association of Iron and Steel Workers. Pittsburgh, PA: Rawsthorne engraving and printing co. Available at http://digital.library.pitt.edu/cgi-bin/t/text/text-idx?idno=00aee8733 $\mathrm{m} \& v i e w=$ toc\&c=pitttext, last accessed on November 12, 2014.

Carver, George 1944. Legend in Steel. The Western Pennsylvania Historical Magazine, Vol. 27, Nos. 3-4, pp. 129-136. Available at http://journals.psu.edu/wph/article/ view/2276/2109, last accessed on November 12, 2014. 
Dorson, Richard M. 1956. Paul Bunyan in the News, 1939-1941. Western Folklore, Vol. 15 (No. 1, pp. 26-39; No. 3, pp. 179-193; No. 4, pp. 247-261).

Dorson, Richard M. 1959. American Folklore. Chicago: University of Chicago Press.

Dorson, Richard M. 1965. The Career of "John Henry". Western Folklore, Vol. 24, No. 3, pp. $155-163$.

Dorson, Richard M. 1976. Folklore and Fakelore: Essays toward a Discipline of Folk Studies. Cambridge, Mass.: Harvard University Press.

Eastman, Crystal 1910. Work-Accidents and the Law. New York: Charities Publication Committee. Available at https://archive.org/details/workaccidentsan00foungoog, last accessed on November 12, 2014.

Fishwick, Marshall W. 1954. American Heroes, Myth and Reality. Washington D.C.: Public Affairs Press.

Fishwick, Marshall W. 1959. Sons of Paul: Folklore or Fakelore. Western Folklore, Vol. 18, No. 4, pp. 277-286.

Foster, William Z. 1920. The Great Steel Strike and its Lessons. New York: B.W. Huebsch Inc. Available at https://archive.org/details/greatsteelstrike00fost, last accessed on November 12, 2014.

Francis, Owen 1931. The Saga of Joe Magarac: Steelman. Scribner's Magazine, Vol. XC (November), pp. 505-511.

Gilley, Jennifer \& Burnett, Stephen 1998. Deconstructing and Reconstructing Pittsburgh's Man of Steel: Reading Joe Magarac against the Context of the 20th-Century Steel Industry. Journal of American Folklore, Vol. 111, No. 442, pp. 392-408. http://dx.doi.org/10.2307/541047.

Jauss, Hans Robert 1974. Levels of Identification of Hero and Audience. New Literary History, Vol. 5, No. 2, pp. 283-317. http://dx.doi.org/10.2307/468397.

Kanigel, Robert 1997. Taylor-Made: 19th-Century Efficiency Expert Frederick Taylor. The Science, Vol. 37, No. 3, pp. 18-23. Available at http://www.ams.sunysb. edu/ weinig/Taylor-made.pdf, last accessed on November 13, 2014.

Karadzic 1845 = Vuk, Karaџiiћ. Srpske narodne pjesme. [Serbian Folk Songs.] Bech: Shtamparija Jermenskog manastira. Available at http://scc.digital.bkp.nb.rs/ document/S-II-0467b, last accessed on November 17, 2014.

Karadzic 1853 = Vuk, Karaџiiћ. Srpske narodne pripovjetke. [Serbian Folk Tales.] Bech: Shtamparija Jermenskog manastira.

Karadzic 1870 = Vuk, Karaџiiћ. Srpske narodne pripovjetke. [Serbian Folk Tales.] Bech: Shtamparija Jermenskog manastira.

Klapp, Orrin E. 1948. The Creation of Popular Heroes. American Journal of Sociology, Vol. 54, No. 2, pp. 135-141. http://dx.doi.org/10.1086/220292.

Klapp, Orrin E. 1949. The Fool as a Social Type. American Journal of Sociology, Vol. 55, No. 2, pp. 157-162. http://dx.doi.org/10.1086/220485.

Klapp, Orrin E. 1956. American Villain-Types. American Sociological Review, Vol. 21, No. 3, pp. 337-340. http://dx.doi.org/10.2307/2089289.

Nelson, Reynolds Scott 2006. Steel Drivin' Man: John Henry, the Untold Story of an American Legend. Oxford \& New York: Oxford University Press.

Rečnik 1981 = Rečnik srpskohrvatskog knjižeunog i narodnog jezika, knjiga XI. [SerbianCroatian Dictionary of Literary Terms.] Beograd: SANU - Institut za srpski jezik. 
Report $1920=$ The Commission of Enquiry, The Interchurch World Movement. Report on the Steel Strike of 1919. New York: Harcourt, Brace and Howe. Available at https://archive.org/stream/reportonsteelstr00inte\#page/n3/mode/2up, last accessed on November 17, 2014.

Reutter, Clifford J. 1980. The Puzzle of a Pittsburgh Steeler: Joe Magarac's Ethnic Identity. Western Pennsylvania Historical Magazine, Vol. 63, No. 1, pp. 31-36. Available at http://journals.psu.edu/wph/article/view/3632/3463, last accessed on November 13, 2014.

Richman, Hyman 1953. The Saga of Joe Magarac. New York Folklore Quarterly, Vol. 9, No. 4, pp. 282-293.

Rječnik 1907 = Rječnik Hrvatskog ili Srpskog jezika, Vol. 26. [Dictionary of Croatian or Serbian Language.] Zagreb: JAZU.

Santino, Jack 1978. Characteristics of Occupational Narratives. Western Folklore, Vol. 37, No. 3, pp. 199-212. http://dx.doi.org/10.2307/1498064.

Taylor, Frederick W. 1915 [1911]. The Principles of Scientific Management. New York \& London: Harper \& Row. 